\title{
PREDICTION OF A NEWBUILDING PROCE OF THE BULK CARRIERS BASED ON GROSS TONNAGE GT AND MAIN ENGINE POWER
}

\author{
Żaneta CEPOWSKA \\ The Association for Praucting of Knowledge About Sea \\ Tomasz CEPOWSKI \\ Maritime University of Szczecin
}

\begin{abstract}
:
The paper presents mathematical relationships that allow us to forecast the newbuilding price of new bulk carriers, based on data concerning vessels built in 2005-2015. The presented approximations allow us to estimate the price based on a gross tonnage capacity and a main engine power The approximations were developed using linear regression and the theory of artificial neural networks. The presented relations have practical application for estimation of bulk carrier newbuilding price needed in preliminary parametric design of the ship. It follows from the above that the use of artificial neural networks to predict the price of a bulk carrier brings more accurate solutions than linear regression.
\end{abstract}

Key words: bulk carrier, newbuilding price, cost estimation, gross tonnage, engine power, design, artificial neural networks, linear regression, approximation

\section{INTRODUCTION}

Ship designer often needs to have estimated prices of different newbuilding vessels. Depending on the available information, pricing of newbuilding's is either approximate or specific.

An estimated price of a new ship is also carried out at its design stage to determine the construction costs and, possibly, the cost of ship operation. Since ship design is a multistage process, at each stage design parameters are optimized relative to the criteria and design constraints, where economic analysis plays an main role. Appropriate conduct of this analysis is the basis for the development of ship design of highest operational values $[3,4,5,6,7,8,11]$.

The preliminary design stage consists of parametric and geometric design phases $[4,8,9,10,12]$. The estimated price of newbuilding should be known at the preliminary design stage. But estimating the price of the ship at preliminary parametric design is difficult. The problem arises from the fact that the price of the vessel depends, inter alia, on the unit costs of ship construction, which in turn include the costs of materials, equipment, labor and the additional costs of the yard $[4,5,7]$. In general, the total of these costs is not known at the stage of parametric design, because at this phase a detailed specification of materials and equipment is not known. During the parametric design only general design parameters of the ship are known, such as main hull dimensions, general geometric indicators, general assumptions regarding the quantity of cargo or ship's speed. For this reason, at this stage the economic analysis covers only basic technical parameters of the vessel, such as weight/displacement, speed or cargo capacity.
In contrast, the subsequent stages of design, when more information is available on the ship to be built, a detailed estimation is performed, considering the unit costs of materials, equipment, labor and additional costs of the shipyard. Methods presented in $[5,6]$ apply to detailed estimation of sea transport means, i.e. vessels.

\section{AIM OF THE RESEARCH}

The aim of the study was to develop mathematical relationships that allow performing cost estimation of bulk carriers built in the years 2005-2015 on the basis of their basic operating parameters.

The practical aim of the research was to develop a mathematical function $f$ for predicting the price of a bulk carrier $\mathrm{P}$ using technical parameters $\mathrm{X}_{1} \mathrm{X}_{2} \ldots \mathrm{X}_{\mathrm{n}}$ :

$$
P \approx f\left(X_{1}, X_{2}, \ldots, X_{n}\right)
$$

where:

$\mathrm{P}$ - newbuilding price,

$\mathrm{X}_{1} \mathrm{X}_{2} \ldots \mathrm{X}_{\mathrm{n}}$ - technical parameters of the vessel,

$n$ - number of parameters,

$f$ - searched-for mathematical function.

The analysis took into account a set of 185 new bulk carriers built in the years 2005-2015, whose parameters ranged as follows:

- gross tonnage GT from 19814 t to $201384 \mathrm{t}$,

- main engine power from $6150 \mathrm{~kW}$ to $29400 \mathrm{~kW}$,

- service speed: 13.5 to 15.5 knots,

- newbuilding price: 20 million to 130 million USD.

In addition to the above parameters the study included:

- displacement, the weight of light ship,

- deadweight, 
Ż. CEPOWSKA, T. CEPOWSKI - Prediction of a newbuilding proce of the bulk carriers based on gross tonnage GT...

- main hull dimensions: length between perpendiculars, breadth, moulded depth, moulded draft.

The study assumed that the function $f$ in equation (1) will be determined using simple linear regression, multiple regression and the theory of artificial neural networks.

\section{USE OF LINEAR REGRESSION FOR APPROXIMATION OF BULK CARRIER PRICE}

Statistical simple linear regression analysis showed that the price of a balk carrier is mainly dependent on main engine power and gross tonnage GT:

$$
\begin{aligned}
& P=15056442+613.02 \times G T \\
& P=12892628+24.88 \times P N 1,5
\end{aligned}
$$

where:

$\mathrm{P}$ - newbuilding price of a bulk carrier in USD,

$\mathrm{GT}$ - gross tonnage [t],

$\mathrm{PN}$ - main engine power [kW]

Equation (2) is characterized by:

- correlation coefficient $\mathrm{R}^{2}=0.79$

- standard error $\sigma=\$ 10.7$ million,

while equation ( 3 ) is characterized by:

- correlation coefficient $\mathrm{R}^{2}=0.82$,

- standard error $\sigma=\$ 9.8$ million.
Figures 1 and 2 show relations (2) and (3) relative to reference data.

Then a multiple regression model was developed for predicting the newbuilding price of a bulk carrier based on the gross tonnage GT and main engine power PN:

$$
P=23643976-1.15 \times 10-8 \times G T 3+0.0014 \times P N 2,5
$$

where:

$\mathrm{P}-$ newbuilding price of a bulk carrier in USD,

GT - gross tonnage [t],

$\mathrm{PN}$ - main engine power [kW].

Equation (4) is characterized by:

- correlation coefficient $\mathrm{R}^{2}=0.83$,

- standard error $\sigma=\$ 9.6$.

Figure 3 shows the prediction of the newbuilding price of a bulk carrier according to formula (4).

\section{USE OF ARTIFICIAL NEURAL NETWORKS FOR APPROXIMA- TION OF BULK CARRIER PRICE}

In many scientific works on hydromechanics and ship design the application of the theory of artificial neural networks to make approximations brought good solutions. In the publications $[1,2]$ the authors used the theory of artificial neural networks to build approximating functions, while [5] shows the possibility of using an analysis of neural network sensitivity to a dependent variable for the selection of independent variables.

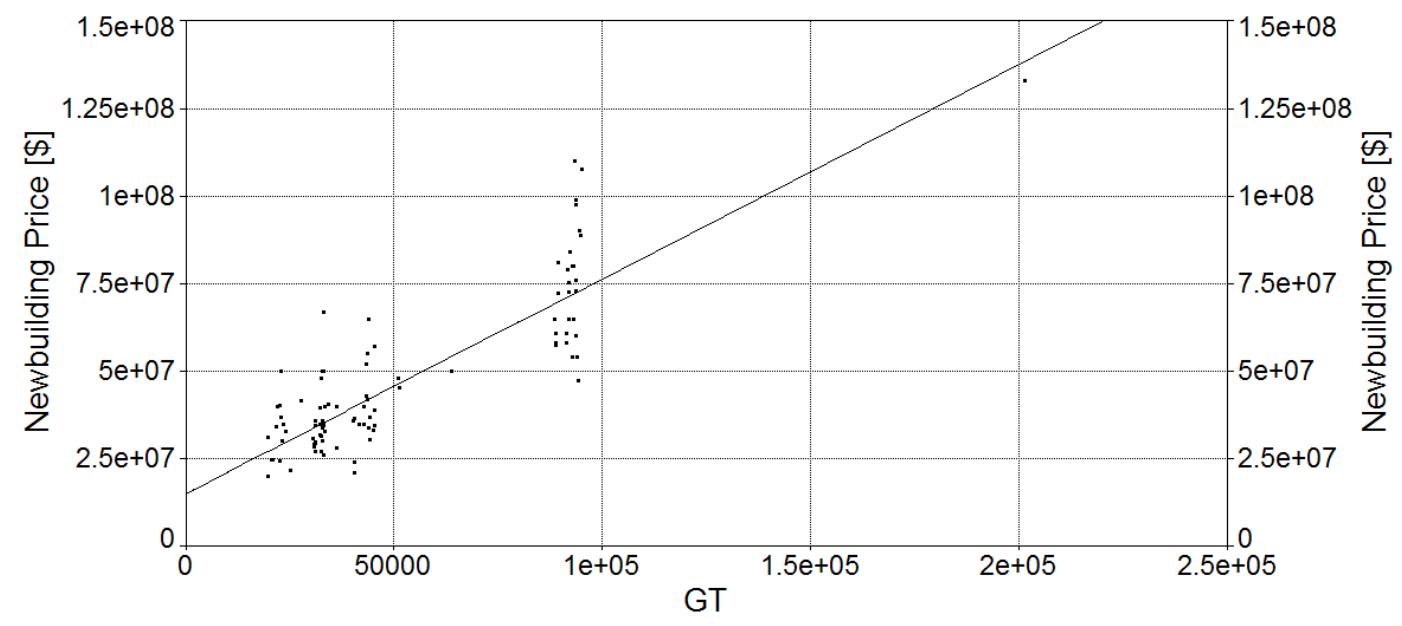

Fig. 1 Approximations of bulk carrier newbuilding price depending on gross tonnage GT, the relationship (2) in comparison with reference data

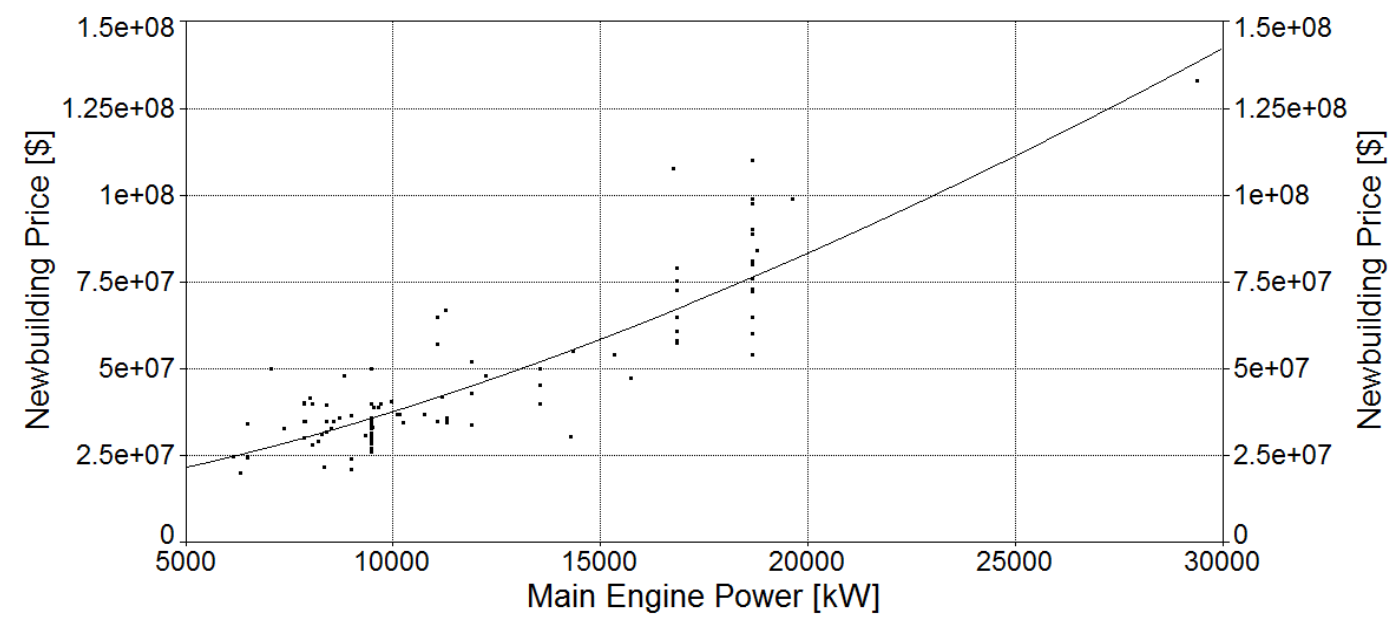

Fig. 2 Approximations of bulk carrier newbuilding price depending on main engine power, relationship (3) in comparison with reference data 


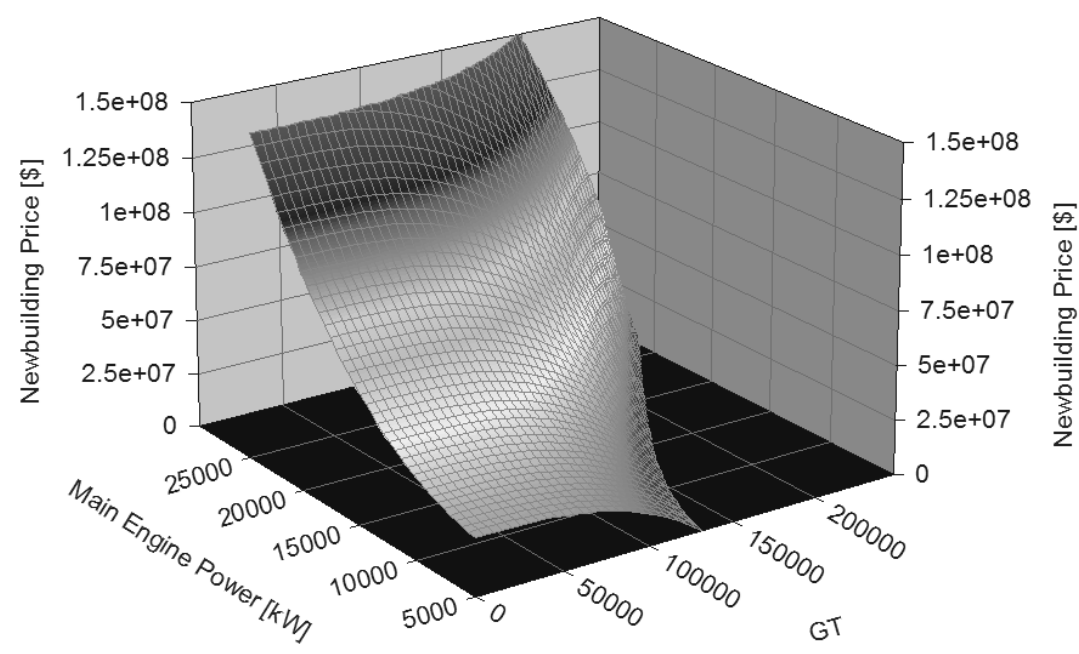

Fig. 3 Projecting the newbuilding price of a bulk carrier depending on the GT capacity and main engine power according to formula (4)

The use of the theory of artificial neural networks for approximating the newbuilding price depending on the GT capacity and main engine power PN produced more accurate solutions than the equation (2) - (4). Author has developed an artificial neural network in the form of a multilayer perceptron having a $2 \times 4 \times 1$ structure (Fig. 4) which can be represented by this mathematical relationship:

$P=\frac{\left(\frac{1}{\left.1+e^{-(([G T, P N] \times S+P) \times A-B)} \times C+0,211\right)-0.1875}\right.}{8.93 \cdot 10^{-9}}$

where:

$\mathrm{P}-$ newbuilding price of a bulk carrier in USD,

GT - gross tonnage [t],

$\mathrm{PN}$ - main engine power [kW],

A - matrix of weight values:

$$
\left[\begin{array}{cccc}
-1.560 & -0.428 & 0.387 & -0.111 \\
-2.493 & -0.486 & -0.285 & -0.501
\end{array}\right]
$$

S- matrix of coefficients:

$$
\left[\begin{array}{cc}
5.51 E-0.6 & 0 \\
0 & 4.30 E-05
\end{array}\right]
$$

B - threshold vector: $\left[\begin{array}{ll}-0.109 & -0.265\end{array}\right]$

C-column vector of weights: $\left[\begin{array}{llll}-1.398 & 0.467 & 0.401 & 0.401\end{array}\right]$

$\mathrm{P}$ - vector of offset values:

$$
\left[\begin{array}{llll}
-2.042052 & 0.58909 & -0.9818 & -0.1733
\end{array}\right]
$$

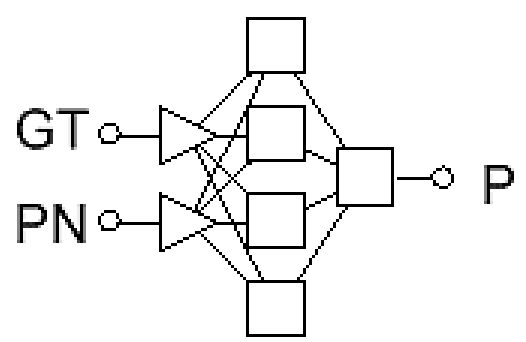

Fig. 4 The structure of artificial neural network for the approximation of the bulk carrier price $P$ according to equation (5), where: $G T$-gross tonnage, $P N$ - main engine power
The artificial neural network described by equation (5) compared to relations (2), (3) and (4), is characterized by:

- the highest value of the correlation coefficient $\mathrm{R}^{2}=0.91$,

- the lowest standard error $=\$ 6.6$ million .

\section{CONCLUSIONS}

The study shows that the price estimate of new bulk carriers is influenced mainly by the gross tonnage capacity and the main engine power. The article presents a series of mathematical formulas that allow to forecast the newbuilding price of a bulk carrier based on these quantities. The relations have been developed from data on newbuilding prices of 185 new bulk carriers built in 2005-2015.

Formula (4), which takes into account both gross tonnage capacity and main engine power is characterized by a slightly higher accuracy than formulas (2) and (3). Therefore, the practical value of this formula is low. Formula (5), in turn, which includes the same independent variables, ie. Gross tonnage capacity and main engine power, is characterized by highest accuracy and lowest error of the developed formulas.

It follows from the above that the use of artificial neural networks to predict the price of a bulk carrier brings more accurate solutions than linear regression.

\section{REFERENCES}

[1] T. Abramowski. "Application of Artificial Intelligence Methods to Preliminary Design of Ships and Ship Performance Optimization", Naval Engineers Journal, vol. 125 (3), pp. 101-112, 2013.

[2] T. Abramowski. "Application of artificial neural networks to assessment of ship manoeuvrability qualities", Polish Maritime Research, vol. 15, No 2(56), pp 15-21, 2008.

[3] V. Bertram. "Resistance and propulsion" in Practical Ship Hydrodynamics, Butterworth-Heinemann, 2000, pp. 62-95.

[4] L. Buczkowski. "Teoria projektowania okrętów" in Podstawy budownictwa okrętowego część II, skrypt Politechniki Gdańskiej, Gdańsk, 1974, pp. 96-181.

[5] W. Chądzyński. "Teoretyczne podstawy procesu projektowania" in Elementy współczesnej metodyki projektowania obiektów pływajqcych, Prace naukowe 
Politechniki Szczecińskiej nr 563, Szczecin, 2001, pp. 39-65.

[6] E.W. Maruszewska. „Applicability of activity based costing in new product development processes", in Management Systems in Production Engineering, No1 (17), pp. 35-39. 2015.

[7] J. P. Michalski. "Parametric method of preliminary prediction of the building costs", Polish Maritime Research, Special Issue, pp. 16-19. 2004.

[8] A. Papanikolaou. "General on Ship Design" in Ship Design. Methodologies of Preliminary Design, SPRINGER, Editor: Apostolos Papanikolaou, 2014, pp. 1-68.
[9] K.J. Rawson and E.C. Tupper. "Some tools" in Basic Ship Theory Hydrostatics and Strength, Elsevier, 2001, pp. 7-52.

[10] K.J. Rawson and E.C. Tupper. "Powering of ship: general principles" in Basic Ship Theory. Ship Dynamics and Design, Elsevier, 2001, pp. 381-423.

[11] H. Schneekluth and V. Bertram. "Main dimensions and main ratios" in Ship Design for Efficiency and Economy, Butterworth/Heinemann, 1998, pp. 2-33.

[12] D.G.M. Watson. "Setting design requirements" in Practical Ship Design, Gulf Professional Publishing, 2002, pp. 35-133.

mgr inż. Żaneta Cepowska

The Association for Praucting of Knowledge About Sea

ul. Wały Chrobrego 1-2, 70-500 Szczecin, POLAND

email: z.cepowska@am.szczecin.pl

dr hab inż. Tomasz Cepowski, prof nadzw. AM

Maritime University of Szczecin

Faculty of Navigation

ul. Wały Chrobrego 1-2, 70-500 Szczecin, POLAND

email: t.cepowski@am.szczecin.pl 